\title{
Initial antimicrobial activity studies of plants of the riverside forests of the southern Uruguay River
}

\author{
Ana Bertucci, ${ }^{1}$ Cristina Olivaro, ${ }^{1}$ Pedro Almeida da Silva, ${ }^{2}$ Daniela Ramos, ${ }^{2}$ \\ Maria Pia Cerdeiras, ${ }^{3}$ Alvaro Vázquez ${ }^{*, 1}$ \\ ${ }^{1}$ Cátedra de Farmacognosia, Facultad de Química, Av. General Flores 2124, Montevideo 11800, Uruguay,
${ }^{2}$ Departamento de Patología, Fundação Universidade Federal do Rio Grande, 96200-190
Rio Grande-RS, Brazil,
${ }^{3}$ Cátedra de Microbiología, Facultad de Química, Av. General Flores 2124, Montevideo 11800, Uruguay
}

RESUMO: "Estudos antimicrobianos preliminares de plantas da floresta ribeirinha do sul do rio Uruguai”. As doenças infecciosas ainda são uma das principais causas de morte no mundo, sendo de significativa importância o desenvolvimento de novos compostos antimicrobianos contra diferentes microrganismos. As plantas podem ser uma boa fonte para direcionar a busca destes compostos. Neste estudo, 66 extratos de 25 plantas da floresta ribeirinha do sul do Rio Uruguai foram estudados para a atividade antimicrobiana contra o Staphylococcus aureus, Listeria inocua, Escherichia coli, Pseudomonas aeruginosa, Mycobacterium tuberculosis, Aspergillus niger e Candida albicans. Cinqüenta e três destes extratos apresentaram algum tipo de atividade antimicrobiana. Seis (Eugenia mansoni, Eugenia repanda, Myrcianthes cisplatensis, Paullinia ellegans, Petunia sp e Ruprechtia laxiflora) apresentaram atividade contra o Mycobacterium tuberculosis com CIM de $50 \mu \mathrm{g} / \mathrm{mL}$.

Unitermos: Atividade antimicrobiana, bioprospecção, Mycobacterium, Candida.

\begin{abstract}
Development of new antimicrobial compounds against different microorganisms is becoming critically important, as infectious diseases are still one of the leading causes of death in the world. Plants can be a useful source of these lead compounds. In this study, 66 extracts of 25 plants of the riverside forest of southern Uruguay River were studied for antimicrobial activity against Staphylococcus aureus, Listeria inocua, Escherichia coli, Pseudomonas aeruginosa, Mycobacterium tuberculosis, Aspergillus niger and Candida albicans. Fifty-three of these extracts showed some kind of antimicrobial activity. Six of these (Eugenia mansoni, Eugenia repanda, Myrcianthes cisplatensis, Paullinia ellegans, Petunia sp and Ruprechtia laxiflora) presented activity against Mycobacterium tuberculosis with MIC values as low as $50 \mu \mathrm{g} / \mathrm{mL}$.
\end{abstract}

Keywords: Antimicrobial activity, bioprospection, Mycobacterium, Candida.

\section{INTRODUCTION}

In spite of the great advance in chemotherapeutics, infectious diseases are still one of the leading causes of death in the world. The World Health Organisation (WHO, 2004) states that infectious and parasitic diseases account for nearly 11 million among the 57 million total deaths in 2003.

Although there seems to be a great array of antibacterial and antifungal drugs in clinical use, the appearance of resistant organisms sometimes makes them ineffective or leads to recurrence.

Higher plants have shown to be an important source of new bioactive compounds including antihypertensive, analgesics, cytotoxic compounds, amongst others (Cassady et al., 1990; Lewis \& Elvin-
Lewis, 1995; Clark, 1996; Amaral et al., 2006; BarbosaFilho et al., 2006a,b,c; Barbosa-Filho et al., 2007; Rocha et al., 2007; Saúde-Guimarães \& Faria, 2007; Araújo et al., 2008; Barbosa-Filho et al., 2008; Corrêa et al., 2008; Sousa et al., 2008). Though no plant derived compound has been found to compete with clinically used antibiotics to date, the great structural variety found in plants makes them attractive as a source of novel lead compounds (Cowan, 1999). In fact, higher plants frequently exhibit significant potency against human bacterial and fungal pathogens (Alonso et al., 1995).

Although Uruguay is usually considered a grassland country it has more than 30 woody families and a considerable amount of native forests, especially along river banks (gallery forests) and "quebradas" 
(gulch forests), with a subtropical and tropical vegetation intrusion (Morrone, 2001; Bertucci et al., 2008). These forests comprise more than 810.000 has with a varied and distinctive flora, around 250 comprising woody and arbustive species (Escudero, 2004). The riverside forest along the Uruguay River banks is especially interesting as a great number of tropical species originary from the Chaco and Espinal floristic provinces are also present (Grela \& Brussa, 2003).

As part of an ongoing project for the native forest bioprospection we identified 54 species belonging to 25 families. Herein we present the results of the antimicrobial screening of 25 of the plant species collected at this site and selected using chemical, pharmacological and ethnopharmacological criteria.

\section{MATERIAL AND METHODS}

\section{Plant material}

Plants were collected during the 2006-2007 summer season in different locations along the Uruguay River shore between the Chapicuy stream confluence and river Guaviyu confluence, near Paysandù. Plants were identified by Lic. F. Haretche, Museo y Jardin Botanico "Atilio Lombardo", Montevideo. Voucher specimens are kept in the MVJB Herbarium, Jardin Botanico, Montevideo.

\section{Extraction}

The plant material was air dried in the dark and milled to a coarse powder. Samples (20 g) were separately twice extracted by maceration with $\mathrm{EtOH} /$ $\mathrm{H}_{2} \mathrm{O}$ 70:30, acetone and $\mathrm{CHCl}_{3}(100 \mathrm{~mL})$ for $48 \mathrm{~h}$. Combined extracts were evaporated under vacuum and lyophilised when necessary.

\section{Microbiological assay}

The antimicrobial activity of extracts to Pseudomonas aeruginosa (ATCC 27853), Staphylococcus aureus (ATCC 6538p), Listeria inocua (CCM-FQ 56), Candida albicans (ATCC 10231) and Aspergillus niger (ATCC 2601) was determined by an agar-diffusion method (Barry \& Thornsberry, 1985).

For Mycobacterium tuberculosis H37Rv (ATCC 27294) the antimicrobial activity was performed by the Resazurin Method developed by Palomino (Montoro et al., 2002) at $200 \mathrm{mg} / \mathrm{mL}$ extract concentration. For those extracts that showed activity at this concentration, a MIC by the aforementioned method was performed.

The microorganisms, except M. tuberculosis were cultured overnight at $35^{\circ} \mathrm{C}$ in blood agar base. Colonies were suspended directly into a small volume of $0.9 \%$ saline and further diluted until the turbidity matched the MacFarland tube $\mathrm{n}^{\circ} 1$ and $2.5 \mathrm{~mL}$ of this suspension added to $100 \mathrm{~mL}$ of molten Mueller-Hinton agar (Difco) for bacteria, and Sabouraud agar (Difco) for yeasts.

The inoculated medium $(20 \mathrm{ml})$ was poured into Petri dishes. Four stainless steel cylinders (ID $1 \mathrm{~cm}$ ) were placed on the surfaces of the medium and $200 \mu \mathrm{l}$ of each extract solution $\left(10 \mathrm{mg} / \mathrm{mL}^{-1}\right)$ pipetted into each of three of them. Two hundred microlitres of gentamicin $\left(20 \mu \mathrm{g} / \mathrm{mL}^{-1}\right)$ or nystatin $\left(50 \mu \mathrm{g} / \mathrm{mL}^{-1}\right)$ were placed into the fourth in order to perform a positive control.

The Petri dishes were incubated at $35^{\circ} \mathrm{C}$ for 24 $\mathrm{h}$ for bacteria and $25^{\circ} \mathrm{C}$ for $48 \mathrm{~h}$ for yeasts. A positive result was recorded if an inhibition zone bigger than the cylinder's diameter was observed. Nystatin and gentamicin were used as controls.

M. tuberculosis was maintained in OgawaKudoh medium for about 14 days. The bacterial suspensions were prepared in sterile water containing glass beads of $3 \mathrm{~mm}$. The suspension was homogenized by vortex agitation and the turbidity was adjusted in agreement with tube $\mathrm{n}^{\mathrm{o}} 1$ of the scale of McFarland (3.2 $\mathrm{x} 10^{6} \mathrm{cfu} / \mathrm{mL}$ ). The inocula was prepared diluting the bacterial suspension 1:25 in Middlebrook 7H9 OADC medium (4.7 g Middlebrook 7H9 base (Difco-Becton Dickinson) enrich with $10 \%$ Oleic acid, Dextrose Albumin, Catalase (OADC-BBL).

\section{RESULTS AND DISCUSSION}

The antimicrobial activity of different plant extracts measured by the agar diffusion method is depicted in Table 1. The MICs determined for plants with a positive assay for $M$. tuberculosis are show in Table 2.

The plants collected for this study were selected using an ethnopharmacological criteria (Cox, 1990), and this accounts for the high levels of positive results obtained (Olano et al., 1996), of sixty-six extracts tested, fifty-three presented some kind of antimicrobial activity.

Myrcianthes cisplatensis has a broad spectrum of antimicrobial activity for all its extracts, even including fungi and Mycobacterium. On the other hand, some others such as Pouteria salicifolia show activity only against a certain group, in this case Mycobacterium and fungi. Paulinia ellegans results one of the most interesting plants. All its extracts show activity against M. tuberculosis and the ethanol/water leaf extract shows activity against Gram negative bacteria as well.

The three species of the Eugenia genus, known locally as pitanga or ñangaripé and used as edible, are especially interesting, showing activity against Mycobacterium, Candida and Aspergillus.

The Petunia extracts showed MIC of $50 \mu \mathrm{g} / \mathrm{mL}$ for M. tuberculosis and despite the fact that it is a high value considering classical antituberculous drugs we believe that it is a good source for bio-guided bioassay.

The MIC of a crude natural extract may or may 


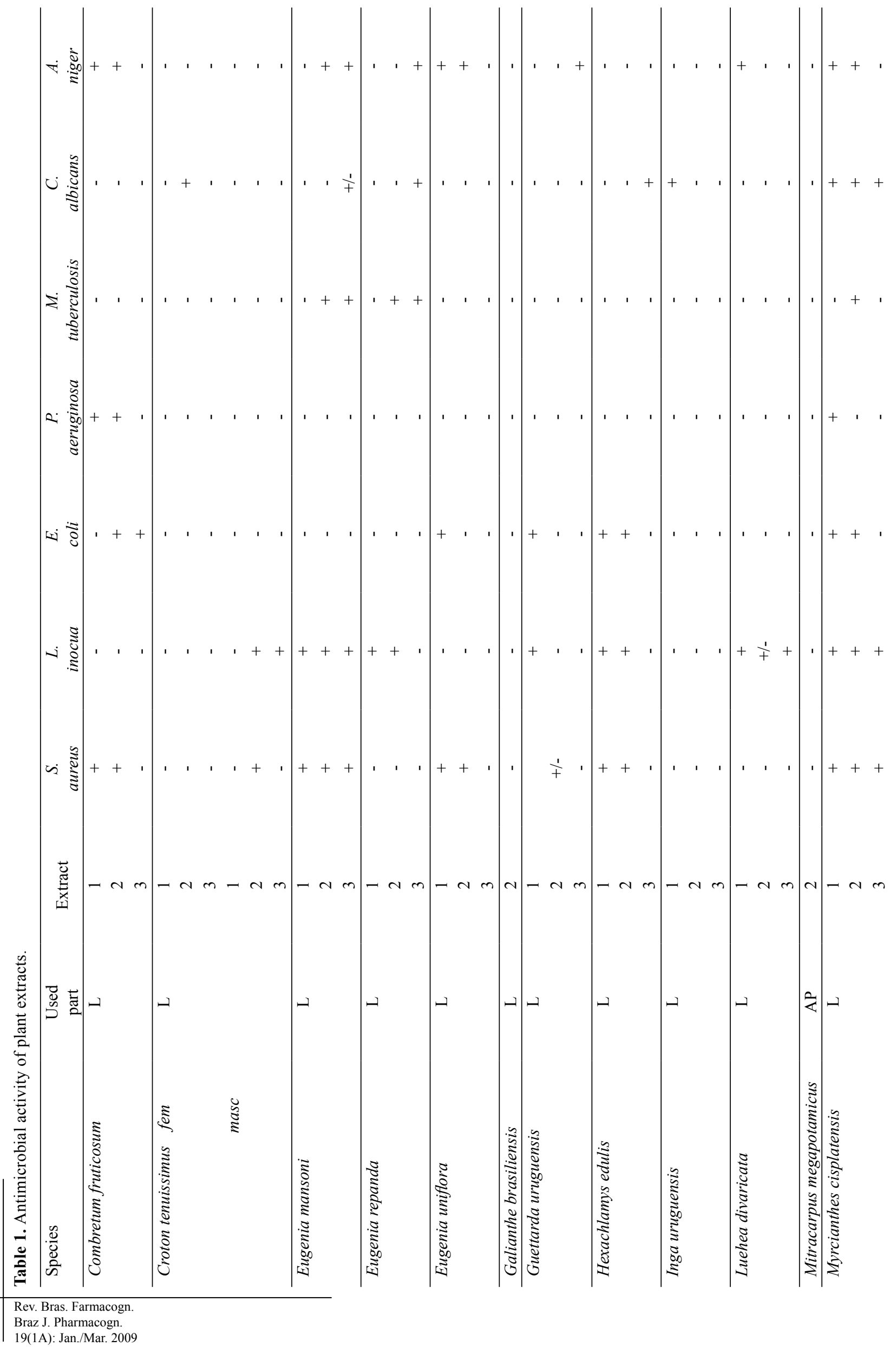




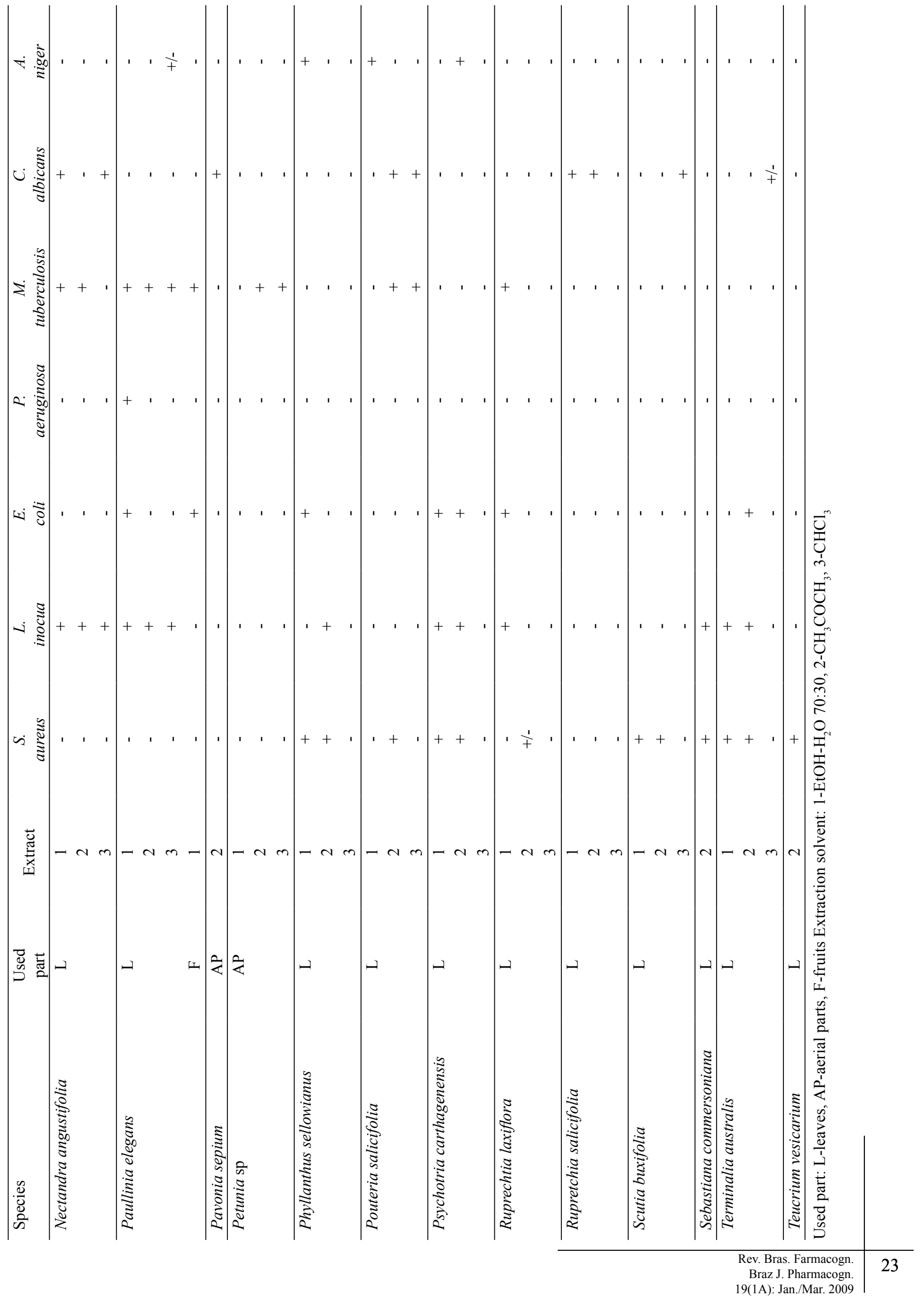


Table 2. Minimum inhibitory concentration of selected extracts against M. tuberculosis H37Rv.

\begin{tabular}{lccclccc}
\hline Species & $\begin{array}{c}\text { Used } \\
\text { part }\end{array}$ & Extract & $\begin{array}{c}\text { MIC } \\
\mu \mathrm{g} / \mathrm{mL}\end{array}$ & Species & $\begin{array}{c}\text { Used } \\
\text { part }\end{array}$ & $\begin{array}{c}\text { Extract } \\
\text { MIC } \\
\mu \mathrm{g} / \mathrm{mL}\end{array}$ \\
\hline \multirow{2}{*}{ Eugenia mansoni } & & & & Paullinia elegans & $\mathrm{L}$ & 1 & $>200$ \\
& $\mathrm{~L}$ & 2 & 200 & & & 2 & 200 \\
Eugenia repanda & & 3 & 200 & & & 3 & 200 \\
& $\mathrm{~L}$ & 2 & 100 & & $\mathrm{~F}$ & 1 & 200 \\
Myrcianthes cisplatensis & $\mathrm{L}$ & 3 & 100 & Petunia $\mathrm{sp}$ & $\mathrm{AP}$ & 2 & 50 \\
& & 2 & 200 & & & 3 & 50 \\
& & 3 & 100 & Ruprechtia laxiflora & $\mathrm{L}$ & 1 & 200 \\
\hline
\end{tabular}

Used part: L-leaves, AP-aerial parts, F-fruits Extraction solvent: 1-EtOH- $\mathrm{H}_{2} \mathrm{O}$ 70:30, 2- $\mathrm{CH}_{3} \mathrm{COCH}_{3}, 3-\mathrm{CHCl}_{3}$

not be a reliable indicator of the chances for success in isolating a potent antimycobacterial agent from that extract. The possibility exists that (i) an extract with a relatively low MIC (high activity) may contain large quantities of only very few moderately active major constituents, or (ii) moderately active crude materials could lead to minor compounds with high activity (Pauli et al., 2005). The extracts with MIC values of 100 and $200 \mathrm{mg} / \mathrm{L}$ will be further studied by bioassay-guided fractionation to search for the active (s) molecule (s).

\section{ACKNOWLEDGEMENTS}

The authors greatly acknowledge the PDT programme (Uruguay) for funding through the grant 32-34. The support of CNPq (Brazil) through Prosul $490204 / 2005-8$ is also acknowledged. This work is part of the collaborative project CYTED-X.11:PIBATUB.

\section{REFERENCES}

Alonso Paz E, Cerdeiras MP, Fernandez J, Ferreira F, Moyna P, Vazquez A, Vero S, Zunino L 1995. Screening of Uruguayan medicinal plants for antimicrobial activity. J Ethnopharmacol 45: 67-70.

Amaral FMM, Ribeiro MNS, Barbosa-Filho JM, Reis AS, Nascimento FRF, Macedo RO 2006. Plants and chemical constituents with giardicidal activity. Rev Bras Farmacogn 16 (Supl.): 696-720.

Araújo EL, Randau KP, Sena-Filho JG, Pimentel RMM, Xavier HS 2008. Acanthospermum hispidum DC (Asteraceae): perspectives for a phytotherapeutic product. Rev Bras Farmacogn 18 (Supl.): 777-784.

Barbosa-Filho JM, Piuvezam MR, Moura MD, Silva MS, Lima KVB, Cunha EVL, Fechine IM, Takemura OS 2006a. Anti-inflammatory activity of alkaloids: A twenty-century review. Rev Bras Farmacogn 16: 109-139.

Barbosa-Filho JM, Medeiros KCP, Diniz MFFM, Batista LM, Athayde-Filho PF, Silva MS, Cunha EVL, Almeida JRGS, Quintans-Júnior LJ 2006b. Natural products inhibitors of the enzyme acetylcholinesterase. Rev Bras Farmacogn 16: 258-285.

Barbosa-Filho JM, Martins VKM, Rabelo LA, Moura MD, Silva MS, Cunha EVL, Souza MFV, Almeida RN,
Medeiros IA 2006c. Natural products inhibitors of the angiotensin converting enzyme (ACE). A review between 1980-2000. Rev Bras Farmacogn 16: 421446.

Barbosa-Filho JM, Nascimento-Júnior FA, Tomaz ACA, Athayde-Filho PF, Silva MS, Cunha EVL, Souza MFV, Batista LM, Diniz MFFM 2007. Natural products with antileprotic activity. Rev Bras Farmacogn 17: 141-148.

Barbosa-Filho JM, Alencar AA, Nunes XP, Tomaz ACA, Sena-Filho JG, Athayde-Filho PF, Silva MS, Souza MFV, da-Cunha EVL 2008. Sources of alpha-, beta, gamma-, delta- and epsilon-carotenes: A twentieth century review. Rev Bras Farmacogn 18: 135-154.

Barry AL, Thornsberry JC 1985. In: Lenette, EH (Ed.), Manual of clinical Microbiology. Washington DC, American Society of Microbiology.

Bertucci A, Haretche F, Olivaro C, Vázquez A, 2008. Prospección química del bosque de galería del río Uruguay. Rev Bras Farmacogn 18: 21-25.

Cassady JM, Baird WM, Chang CJ 1990. Natural products as a source of potential cancer chemotherapeutic and chemopreventive agents. J Nat Prod 53: 23-41.

Clarck AM 1996. Natural products as a resource of new drugs. Pharm Res 13: 61-70.

Corrêa MFP, Melo GO, Costa SS 2008. Substâncias de origem vegetal potencialmente úteis na terapia da Asma. Rev Bras Farmacogn 18 (Supl.): 785-797.

Cowan MM 1999. Plant products as antimicrobial agents. Clin Microbiol Rev 12: 564-581.

Cox PA 1990. Ethnopharmacology and the search for new drugs. In: Chadwick, DJ, Marsh, J (Eds.), Bioactive compunds from plants. Chichester, John Wiley\&Sons, pp 40-48.

Escudero R 2004. Manejo y Conservación de la diversidad Biológica: Bosque Nativo. Montevideo, GEF/IBRD, pp 32-46.

Grela I, Brussa C 2003. Relevamiento florístico y estudio comparativo de las comunidades arbóreas de la Sierra de los Ríos. Agrociencia 7: 11-26.

Lewis WH, Elvin-Lewis MP 1995. Medicinal plants as sources of new therapeutics. Ann Mo Bot Gard 82: 16-24.

Montoro E, Lemus D, Echemendia M, Martin A, Portaels F, Palomino J C 2002. Comparative evaluation of the nitrate reduction assay, the MTT test, and the resazurin microtitre assay for drug susceptibility testing of clinical isolates of Mycobacterium 
tuberculosis. Int J Tuberc Lung Dis 8: 253-259.

Morrone JJ 2001. Biogeografía de América Latina y el Caribe. Zaragoza, CYTED-ORCYT/UNESCO - SEA Cooperación Iberoamericana. Manuales y Tesis vol 3, pp 122-148.

Olano I, Paz EA, Cerdeiras MP, Fernandez J, Ferreira F, Moyna P, Soubes M, Vazquez A, Vero S, Bassagoda MJ 1996. Screening of Uruguayan medicinal plants for antimicrobial activity. Part II. J Ethnopharmacol 53: $111-115$

Pauli GF, Case RJ, Inui T, Wang Y, Cho S, Fischer NH, Franzblau SG 2005. New perspectives on natural products in TB drug research. Life Sci 78: 485-494.

Rocha FD, Pereira RC, Kaplan MAC, Teixeira VL 2007. Produtos naturais de algas marinhas e seu potencial antioxidante. Rev Bras Farmacogn 17: 631-639.

Saúde-Guimarães DA, Faria AR 2007. Substâncias da natureza com atividade anti-Trypanosoma cruzi. Rev Bras Farmacogn 17: 455-465.

Sousa FCF, Melo CTV, Citó MCO, Félix FHC, Vasconcelos SMM, Fonteles MMF, Barbosa-Filho JM, Viana GSB 2008. Plantas medicinais e seus constituintes bioativos: Uma revisão da bioatividade e potenciais benefícios nos distúrbios da ansiedade em modelos animais. Rev Bras Farmacogn 18: 642-654.

WHO 2004. The World Health Report 2004: Changing history. Geneva, WHO. 